\title{
A feminist poststructuralist analysis of Discourses invoked in the construction of women's leadership identities in higher education
}

Book or Report Section

Accepted Version

Jones, K. (2020) A feminist poststructuralist analysis of Discourses invoked in the construction of women's leadership identities in higher education. In: Samier, E. A. and Milley, P. (eds.) Educational Administration and Leadership Identity Formation: International Theories, Problems and Challenges. Routledge, Abingdon, pp. 1-33. ISBN 9780367272906 Available at https://centaur.reading.ac.uk/86523/

It is advisable to refer to the publisher's version if you intend to cite from the work. See Guidance on citing.

Publisher: Routledge

All outputs in CentAUR are protected by Intellectual Property Rights law, including copyright law. Copyright and IPR is retained by the creators or other copyright holders. Terms and conditions for use of this material are defined in the End User Agreement. 


\section{www.reading.ac.uk/centaur}

\section{CentAUR}

Central Archive at the University of Reading

Reading's research outputs online 
Edited collection book chapter, reference:

Jones, K. (2020) A feminist poststructuralist analysis of Discourses invoked in the construction of women's leadership identities in higher education. In: Samier, E. A. and Milley, P. (eds.) Educational Administration and Leadership Identity Formation: International Theories, Problems and Challenges. Routledge, Abingdon, pp. 1-33. ISBN 9780367272906 


\title{
A feminist poststructuralist analysis of Discourses invoked in the construction of women's leadership identities in higher education
}

\author{
Karen Jones
}

Orcid.org/0000-0001-5154-4583

\begin{abstract}
The scholarly literature has witnessed many twists and turns in recent years as traditional 'old' style feminist discourse of discrimination and sexism has been replaced by a postfeminist Discourse of autonomy and choice (Gill 2014, Gill and Scharff 2013, Gill et al. 2017). Most recently a 'new' style of empowered feminist activism has (re)surfaced where women claim their voice to speak out against a wide range of issues, such as gender inequality, cultural sexism and masculine hegemony, to name just a few issues within society and specific vocational contexts. The analytical framework in this chapter draws on contemporary theorising of postfeminist and neoliberal Discourses and Discourses of gender and leadership. Focusing on women in higher education and adopting a feminist poststructuralist approach, which views language and discourse spoken as constituting subjectivity, this chapter will consider through a meta-analysis of empirical work, how women's professional identities are shaped and constrained by competing dominant Discourses. The analysis examines the identity work invoked in women's accounts of their workplace experiences in higher education,
\end{abstract}


to illuminate how prominent Discourses are taken on by women and enacted as part of their professional identities.

\section{INTRODUCTION}

The starting point for this chapter is the statistical underrepresentation of women in leadership in higher education globally, and discrimination toward women as leaders. The resulting complexities and ambiguities for women's professional identities is explored from a feminist poststructuralist perspective, in which language and discourse is viewed as constituting subjectivity (Weedon 1997). This topic and approach offers insight into the problematic nature of identity. Feminist poststructuralists highlight the significance of power in the construction of identity through women's difference in the workplace, and way Discourses shape social practices (Ford 2006). Although individuals have some agency in the construction of their identities, that agency is shaped by language and the Discourses available (Jaros 2012). In consequence, subjects are limited to some extent by social structures, power relations and other actors in their social context (Alvesson and Due Billing 2009: 99).

Following Gee (1990), the chapter considers discourse at two levels - big D Discourse reflects socially based conventions for ways of behaving, interacting, thinking, speaking that are considered as acceptable enactments of specific identities and activities (for example, taken for granted ideas of how a leader should behave or dress). Little d 'discourse' refers to how big D Discourse flows 
in talk (little d discourse). Managerially inspired Discourses and broader social Discourses provide an important resource, not only for how professional identities should be enacted, but also for how women should respond to difference and discrimination in the workplace. This is because Discourse reflexively constrains and permits what is sayable and enacted on in talk (discourse) (Jones and Clifton 2018).

Specific to Discourse, the scholarly literature has witnessed many twists and turns in recent years as traditional 'old' style feminist Discourse of discrimination has been replaced by a postfeminist Discourse of autonomy and choice (Gill 2014; Gill and Scharff 2011; Gill et al. 2017). Most recently a 'new' style of empowered feminist activism has surfaced, most notably through the media, prompting a wave of \#feminism, where women claim their voice to speak out against a wide range of issues, such as gender inequality, cultural sexism and masculine hegemony, to name just a few issues within society and specific vocational contexts. This includes the academy (see e.g., Harley 2003; Harding et al. 2010; O’Connor 2014; Savigny 2014; Morley and Crossouard 2016). In consequence, women are caught in the middle of competing Discourses, which produce opposing models that they can act on in response to two fundamental questions of identity: 'who am I?'- and related to that - 'how should I act?' (Cerulo 1997). The feminist discussion in this chapter is based on Western feminism and is therefore different to Islamic feminism, for example. 
The chapter promises to illuminate how dominant Discourses have taken root in the academy and become part of women's identities through a meta-analysis of prior empirical research with women in senior leadership and middle management higher education roles in four international contexts (China, United States, United Kingdom and Australia). Thus, the contribution of the chapter is both theoretical and empirical.

The chapter begins by exploring issues surrounding women's leadership in higher education then identifies links between dominant Discourses of gender and leadership, followed by post-feminism and neoliberalism, and the influence of the feminist renaissance (Rottenberg 2018). The next section explains the selection of the case studies and analytical approach. Following that the analysis and discussion, based on empirical data with women in higher education in four countries locates the construction of identities in the context of dominant Discourses and cultural practices. It extends prior empirical work and offers a critical feminist theorising of pervasiveness contemporary Discourses that contribute to maintaining gender inequalities in the academy.

\section{WOMEN AND LEADERSHIP}

For researchers interested in women's leadership, higher education presents contradictions on a global scale. The picture of women's status in higher education is at first glance positive. Women have made significant advancements 
in higher education participation and employment over the past two decades and increasingly women are taking up leadership positions. Women now lead some of the World's most prestigious institutions, such as the University of Oxford and Imperial College, London, in the United Kingdom and the University of Pennsylvania in the United States of America. Notwithstanding these very welcome improvements, closer scrutiny of statistical evidence reveals that only 34 (17 per cent) of the top 200 universities in the world are led by women (Times Higher Education 2019). There is indeed a serious deficit of women in senior and leadership roles in higher education globally (Morley 2013). To serve as an example, just 29 per cent of all vice chancellors of institutions in the UK are women and only 25 per cent of professors are women (Jarboe 2018).

In passing comment on this, it is an irony that universities are heralded as vanguards for social justice and socio-cultural change, especially in relation to diversity and inclusion. This, along with the deficit of women in senior roles and leadership has prompted many feminist scholars to question why women are not adequately recognised, developed, selected or promoted into the upper echelons of institutions (Ibarra et al. 2010; Manfredi et al. 2014; Shepherd 2017; Jones et al. 2018; Morley 2010, 2013, 2016; Singh 2008; Brink et al. 2010). In response to what David (2015) calls rampant gender inequalities within Higher Education, a constellation of criticism is pointed at the academy. This includes accusations that it harbours patriarchal and corporatised cultures, which encourage intensified competitiveness and lead to hostile and aggressive work practices and power 
imbalances (Morley and Crossouard 2016). A bleak picture is painted of gender bias and misrecognition, exploitation, bullying and cultural sexism (Savigny 2014; Brink and Benschop 2012). In addition to creating barriers to leadership for women, this can result in alienation and feelings of lack of belonging, which can cause women to dis-identity with leadership (Vicary and Jones 2017).

\section{DISCOURSES OF GENDER AND LEADERSHIP SHAPING IDENTITIES}

It follows that higher education is a context where for women (and other minority groups), the construction of identity intersects with issues of difference, power and control. Since leaders within the academy are predominantly male, masculine prototypes of leaders' attributes and characteristics become the norm and feed into masculine Discourses of leadership (Eagly and Karau 2002). For performances of leadership to be taken seriously, they must be infused with 'stage-craft' and 'stage management' (Goffman 1959: 26). Lamsa and Sintonen (2001) argue that although leadership is not produced simply through socialisation, because women hold a subjugated position within the institutional hierarchy and male authority is the norm, cues rooted in hegemonic notions of leadership learnt tacitly become natural and taken for granted. In consequence 'women's academic identities are often forged in otherness, as strangers in opposition to (privileged) men's belonging and entitlement' (Morley 2010:.38). 
Partly to counter masculine Discourses of leadership, a Discourse of women's leadership has emerged, which emphasises women's so-called advantage in leadership. This is founded in the stereotype that women possess inherent natural capabilities that enable them to be more relational leaders, socially competent, collaborative and caring as leaders. This is highly problematic since it essentialises women and reduces the possibilities for alternative forms of leadership to be practiced by women without criticism.

Taken together Discourses of gender difference and underrepresentation simultaneously position women as other to the male norm. Speaking of female students in computer science education, Convertino (2019) argues that otherness and difference make women highly invisible and visible at the same time. This is true for women in higher education. Discourses of gender and leadership make women highly visible by their ascendancy to almost hero status when they become senior leaders and because they embody difference. This makes women highly visible as an outsider or imposter in leadership teams where men are a majority. Women are also highly visible as the focus of initiatives, policies and plans to address gender imbalances in leadership. Initiatives targeted at increasing women's participation in leadership tend to contribute to a deficit model of women as failed leaders or lacking in fundamental ways. Women are encouraged to improve themselves by joining women's networks, leadership development and mentoring programmes. Such initiatives seek to upskill women and address socalled confidence issues, empower and motivate women to step up to leadership. 
Ironically this reminds women of their shortcomings and the need to work on themselves. As this chapter will show, this speaks to the privatising and individualising of responsibility reflected in neoliberal and postfeminist thinking.

One can conclude from this that the formation of leadership identity and acceptance within higher education communities of practice for women is shaped by patriarchal cultures and Discourses of gender and hegemonic notions of leadership. Alvesson and Willmott (2002) argue that organisational cultures and managerial Discourses of empowerment and participation, fuelled by the rise of neoliberal ideology make the workplace more precarious and contribute to destabilising employees' sense of self. This gives rise to anxiety. They argue that because self-stability is an inherent human need, employees attempt to address existential issues and reduce anxiety (O’Doherty and Willmott 2001). They do this by engaging in considerable identity work and identity regulation to develop self-images and work orientations that convey commitment to organisational goals (Alvesson and Willmott 2002). While there are possibilities for individuals to exercise agency through expressions of resistance and subversion against control and oppressive employment practice (Alvesson and Willmott 2002), gender identity and related gendered roles are shaped and regulated by powerful Discourses. Some of these are organisational in nature, while others are broader and societal in nature. (Alvesson and Billing 2009; Jaros 2012). 
Turning to broader societal Discourses, research shows that in cultural contexts where women are still valued for traditional roles, such as being a mother and caring for others, women often construct their identities to conform to such social norms and expectations (Zhao and Jones 2017). This can profoundly shape the way that individuals construct their identities in communications with other people.

Taken together, institutional and societal level cultural practices create the social norms that one is required to abide by to be accepted by others. This chapter is concerned with how the Discourses available have a profound impact on identity development (Gee 1990). It turns to contemporary feminist Discourses next.

\section{POST-FEMINISM}

Postfeminist sensibility encapsulates paradoxes in contemporary culture, where on the one hand women are characterised as having agency, freedom, empowerment and choice, but at the same time: 'women are currently being disempowered through the very discourses of empowerment they are being offered as substitutes for feminism' (McRobbie 2009: 49). This has captured the imagination of contemporary writers to critique how women and femininities are being included in the modern workplace. (Lewis 2014). 
Gill and Scharff (2013) describe four broad ways post-feminism is used in such research. First, to signal an epistemological break within feminism, especially second wave feminist epistemologies of femalehood, which have been criticised for propagating essentialist assumptions that 'patriarchal and imperialistic oppression was a universally experienced oppression' (Brooks 1997: 4). Second, to signal the rejection of a universal category of 'woman' (Genz and Brabon 2009). This aligns with shifts in theorising that marks the intersection of feminism with anti-foundational movements, such as post-modernism, poststructuralism and post-colonialism (Brooks 1997). Lewis (2014), argues this is not a rejection of feminism per se, rather acknowledgment of its ongoing metamorphosis and coming of age. A third use of the term is to periodise post-feminism within feminism. This tends to be as a stage after the height of the second wave feminism and sometimes synonymously with third wave feminism, especially in the United States of America (Gill and Scharff 2013; Gill et al. 2016). Fourth, post-feminism is used as a critical term in the analysis of postfeminist culture (Gill 2016). From this perspective post-feminism is viewed as a sensibility (Gill 2007), meaning 'an object of critical analysis, rather than as a theoretical orientation, new moment of feminism or straightforward backlash' (Gill and Scharff 2013: 4).

Postfeminist sensibilities instil the notion that individualism, empowerment and choice is the route to independence and freedom, and any retreat to the home to fulfil traditional female gender roles (caring, mothering) is a matter of choice. This invokes a Discourse that fosters the myth that all the battles have been won 
(Gill 2014), and that feminism is no longer needed because equality has been achieved (McRobbie 2009; Genz and Brabon 2009; Kelan 2009). In consequence, research shows that women often disavow gender inequalities, and instead attribute discrimination they experience to other factors such as age and experience (Gill 2014).

NEOLIBERALISM AND POST-FEMINISM

Lewis (2014), Gill et al. (2017) and Lewis et al. (2017) argue that post-feminism shares many features with neoliberalism. post-feminism fosters a Discourse of meritocracy and egalitarianism that views individuals as 'active, free choosing and self-reinventing subjects', which bears an uncanny resemblance to 'the autonomous, calculating, self-regulating subject of neoliberalism' (Gill and Scharff 2013: 7). Both concepts promote individualism, to the denial of social, political or external constraints or influences on individuals and require women (more than men) to undergo personal transformation, for example, to make themselves more confident or resilient (Gill et al. 2017: 231). Neoliberalism compels women to embrace entrepreneurial subjectivities of self-surveillance, self-improvement and self-discipline. 'Otherness and any other workplace disadvantage are viewed as matters of individual responsibility and ambition, never as structural phenomena' (Berglund et al. 2017: 6). Similarly, postfeminist promotes notions of choice and the rejection of structural barriers (Lewis et al. 2017). Rottenberg $(2013,2018)$ refers to this as neoliberal feminism. 
\#FEMINISM - THE FEMINIST RENAISSANCE

post-feminism and neoliberal Discourse is seemingly incompatible and markedly juxtaposed with new popularised feminist activism propagated through social media, ostensibly in the form of the \# me too campaign. Stemming from the steady stream of media reports of sexism and sexual harassment in different industries and spheres of society around the World, it has been claimed that we are in the midst of a contemporary feminist renaissance (Rottenberg 2018). A new form of \#feminism has emerged, and in consequence, a new feminist sensibility where feminism is espoused with pride, to the extent that an unprecedented number of high-profile corporate women, along with celebrities and royalty Megan Markle, the 'feminist princess', are now embracing the ' $\mathrm{f}$ ' word (Rottenberg 2018). A 'new' style of feminist Discourse has emerged in a language infused with power, protest, mobilisation and discontent. This has made it virtually impossible to ignore that equality for women has not been fully achieved (Keller 2011).

ANALYSING THE ROLE OF COMPETING DISCOURSES IN THE CONSTRUCTION OF IDENTITIES

This chapter has outlined the importance of Discourses in shaping workplace identities. Offering a feminist poststructuralists perspective, it discounts the notion 
of gender as a pregiven identity, by emphasising the role of Discourses and cultural practices that create the subject positions available to women (Convertino 2019). This is elaborated on in a meta-analysis of four empirical studies, drawn from different international contexts, first China (Zhao and Jones 2017), then the United States (Dunn et al. 2014), and finally two studies by Burkinshaw and White (2017) in the United Kingdom and Australia.

The articles were purposively selected as information rich sources. The first study (in China), was originally co-authored by the author of this chapter. It is extended here with a postfeminist reading of the role of cultural practices in the construction of identities. Three other articles were identified through key terms (women/female, leadership, higher education/administration). It is acknowledged that the study has limitations The selection of articles was shaped to an extent by the subjectivity of the author. Except for the first study (in China), the author of this chapter was not involved in the design of the primary research or datacollection. Secondary analysis was limited to published findings, not primary datasets. This raises questions about the trustworthiness of the data. The original studies did not explore the same issues this chapter is exploring, so there is an element of first author bias in the data included in those articles. The studies and original authors' analysis and interpretations are timebound to the literature available when they were conducted. To address these limitations only articles that had been subjected to peer review and published in the past five years were included. The underlying literature and data were assessed to establish a match 
with the issues for exploration in this chapter. Part of the criteria was that they provide a fruitful source to direct ongoing research efforts with new analysis and the development of theoretical explanations. Articles were assessed for rigour in terms of transparency, trustworthiness, reliability and dependability of the sources and data. The final selection was made to reflect different international contexts.

The analysis began with familiarisation, which involved repeated cycles of reading to identify themes. Fine-grained analysis of selected segments was guided by discursive approaches and involved iterative cycles of inquiry between the data and theory (Wiggins 2017). First, dominant Discourses were identified in the narrative, then the discursive strategies adopted by the women were examined (e.g. downplaying an experience or justifying a course of action), to pinpoint subject positioning and elicit how they responded to dominant Discourses. Different dimensions of identities were explored, such as the identity work invoked by Discourses, ideological aspects of Discourses and their influence on subjectivities, and the nature of identities enacted in the workplace, as disclosed in interview talk. Following Gee (1990) this analysis distinguishes between discourse (little-d), as micro-practices of talk, and Discourse (big-D) as a system of understanding that prefigures which practices and interpretations are available to individuals.

\section{Case study 1. Cultural practices - Discourses of gender and leadership in}

\section{China}


Zhao and Jones' (2017) study involved interviews with nine women from two universities in China at different career stages and leadership levels. Four were Instructors/Teachers with responsibilities as Secretary of the Youth League Committee. Five women served in more senior leadership roles, one as Dean (head of school), another as Associate Dean, two as Department Directors and one as Section Chief. The study explored how they defined their identities and the female leader identity more generally, and how their discourse was intertwined with broader societal Discourses of gender and leadership. A postfeminist interpretation was not provided in the original article.

The findings contribute to understanding how powerful historical and cultural ideologies in China generate Discourses of gender (virtuous wife, good mother), and how this is enacted in talk by women working in higher education Diversity in the sample meant comparisons could be made between women at different career stages and leadership levels, although no differences were found. For example, the female Dean said: 'household is the most important thing for a woman, happiness of the family is most important of all.' Similarly, one of the Instructors said: 'I think men should do great things, and women should get small things done' (135). Notions of pre-given natural sex differences emerge in statements such as: 'the different genes result in male's rationality and female's sensibility, which no one can change' (138). The women did not claim they had no choice in this matter, nor did they express discontent or protest about their 
subjugated position in gender hierarchies. Differences were invoked as normal and natural, not attributable to patriarchy.

It follows that this renders women in Chinese Higher Education particularly unsuited to leadership. Illustrative of this, none defined themselves as a leader. Rhetorical devices to ward off any claims of a leader identity ranged from downplaying their leadership role to outright rejection. For example, one senior leader said: 'I never treat myself as a leader', then downgraded this by saying it is '... more like coordination'. She positioned herself as lacking agency by stating 'my responsibility is to do the tasks which are assigned by the superior'. This was qualified with the statement 'I think it is normal' (136).

Reflective of the virtuous wife and caring mother Discourse permeating Chinese society, the women tended to categorise their multiple identities in hierarchical importance as 'a good mother, then a good teacher, and last a good manager' (136). Many of the women preferred to be referred to as a 'teacher and only a teacher' or by their name (135). 
Clearly a postfeminst reading derived from Western theories does not account for China's unique culture or history with feminism. China has not had a feminist movement like Western cultures. Throughout the $20^{\text {th }}$ century feminism was interwoven with socialism and class issues and more recently the \#MeToo movement, although this has been severely curtailed due to limitations on freedom of expression and punitive measures for activists (Cunningham, 2016). The notion of postfeminist sensibilities is still embryonic, however, postfeminism of Western popular culture has related to female subjectivity in China (Thornham and Pengpeng 2010). The postfeminist reading offered here provides a unique interpretation in an organisational setting. As illustrated in segments of narrative, the women drew on Discourses in Chinese culture that epitomise a set of ideas about the ideal femininity (e.g. virtuous wife, good mother). They referred to men as reasonable or rigorous and decisive, whereas women were characterised as delicate and more considerate and sensitive. This reflects postfeminist sensibilities that encapsulate notions of ideal femininity, retreat to the home as a matter of choice and natural sex differences (Gill 2007, Lewis 2014). Central to postfeminst Discourse is the notion that practices are chosen freely and women are autonomous in their choices, as suggested in these interviews.

\section{Case study 2. Discourses of women's leadership and backlash in the United}

\section{States}


The meta-analysis turns next to research with three senior women administrators to explore the career trajectories and development of female academic leaders of higher education in the United States (Dunn et al.2014). These women discursively constructed their identities as strong, confident, professional, passionate and successful leaders. At the same time, their accounts invoke a Discourse of gender difference related to male-normed leadership practices. The unwritten rules of conduct for senior leaders was not directed from above, but the women internalised male-normed practices, self-governed their behaviour and took responsibility for any perceived shortfall. For instance, one woman said:

unfortunately, my leadership style only served to reinforce the gendered stereotypes held by colleagues (e.g., women as weak leaders). In consequence, I resorted to becoming more directive and authoritative.

(Dunn et al. 2014: 12).

Interpreting what passes for leadership in practice and reproducing that to transform oneself, produces what Gill (2014) refers to as new labouring subjectivities, which she argues is 'indicative of the way in which power and compulsion operate psychosocially, through a remade worker subjectivity that is hyper-conscientious and 'responsibilised' - but also, it should be added, profoundly anxious, and fearful of being displaced' (516). Typically, this results in considerable identity uncertainty, identity regulation and ultimately identity work (Alvesson and Willmott 2002). Rather than exercising agency with 
expressions of resistance, one strategy the women adopted was to fit in by learning to lead in ways that mirrored the practices of their male counterparts, albeit reluctantly. Once more this reflects postfeminist Discourses and neoliberal ideology that entices individuals not to be held back by institutional sexism, but to exercise self-discipline, be calculating and take full responsibility for selfimprovement (Gill 2007; Lewis 2014).

The second strategy used by the female senior administrators draws heavily on Discourses of gender and leadership. A striking feature of the narrative is a passionate dedication to selfless leadership. The accounts produce an abundance of examples of tireless labouring to facilitate the work of others, by always giving credit to others and enabling others to shine. Common patterns of long work hours, selfless dedication to the job, and sociability in the form of relational leadership appear in these accounts, which speak to neoliberal ideals. In common with women leaders in China, the women used rhetorical devices to downplay their own accomplishments, for example one said: 'the credit for those [achievements] and other efforts must go to others' (12). Thus, Discourses of gender difference emerge strongly in their accounts, in relation to their enactment of leadership. In articulating their deployment of relational and transformational forms of leadership, the women drew on maternal Discourses of nurturing others and letting others shine, perhaps to produce an acceptable version of feminine leadership. 


\section{Case study 3. Fitting in UK higher education or getting out in Australia - signs of a feminist renaissance}

Research by Burkinshaw and White (2017) focuses on two generations of women in separate studies. The first study involved 18 women who were senior leaders in higher education institutions in the UK (Vice-Chancellors / principal / presidents) The second study involved 85 younger women in middle management roles at a newer Australian university who had completed a women's leadership programme. The samples for the original studies were selected to explore gendered leadership cultures in higher education and the learning of leadership. Gender difference is invoked in both, but the response from women in each study is strikingly different.

First, the interviews with senior women leaders in the UK generate a discourse of gender difference that focuses on masculine communication and leadership practices. They described institutional cultures as 'male dominated' and labelled men as loud, domineering, vocally assertive and confident (87). They were acutely aware they could not 'behave like that because it's not seen the same way' (88). To this end, they worked hard to fit-in with male culture by regulating their identities, sometimes to deny femininity. Reflexively interpreting a lack of congruity between self-identity and what they perceived to be a desirable social identity, they consciously invested in remedial work to accomplish desirable social attributes and leadership traits. They took personal responsibility for any 
perceived shortcomings, to fit-in for survival, by emulating men, adopting an air of male feistiness and, echoing elements of the make-over paradigm epitomised by postfeminist sensibility, some embodied leadership by power dressing. For example, one woman said: 'in the early days, it was power suit dressing time and there was a lot of emulating of what men would have done. I was not immune to that' (89).

By maintaining emotional control and suppressing their preferred leadership practice and natural ways of behaving, many of the dynamics of neoliberalism and post-feminism are present. As shown in the previous case of women in the US (Dunn et al. 2014), this predominantly involved self-discipline and selfimprovement, which was achieved by working hard and working on oneself. This is known to occur in response to changes in the workplace that cause disruption, tension, confusion or a feeling of being unsettled about 'being myself' (Alvesson and Willmott 2002: 626). Although the women were highly aware of their choices and critical of masculinised cultures in higher education, the data provided in the study does not reveal if the women articulated action to protest or dispel the myth of meritocracy in their institutions. Of course, the absence of action statements could well be a remnant of the limitations of the data in the reviewed source.

By contrast, the younger generation of women in middle management roles at an Australian University appeared to embrace the feminist renaissance (Rottenberg 
2018) encapsulated by \#feminism. In calculating they were expected 'to develop self-images and work orientations that are deemed congruent with managerially defined objectives' (Alvesson and Willmott 2002: 619), their discourse provides insight into the identity work this invoked. This reveals a self-identity that was as precarious as the women in the UK, but their narratives bear strong resistance to identity work required to reproduce the masculine norm. They were highly critical of' 'poor (mostly male) leadership models' which might 'pass as leadership' and did not want to 'play the game' or 'emulate the poor leadership' (90). Illustrative of feelings of discontent, anger and frustration emerging in accounts from this study, one women said that having time to reflect on her career and the 'workings of our university' had 'acted to convince me that I am a poor fit with this university’ (91).

In contrast with the previous accounts, these women refused to engage in identity work that would neatly align with neoliberal, masculinised institutional cultures. Their message was 'stop trying to fix the women and instead try to improve working conditions and career opportunities for women' (90). Mobilising Discourses that reflect a feminist renaissance (Rottenberg 2018), this younger generation of women exercised agency in the construction of their identities. They recognised and defied the masculine symbolic order and were vocal speaking out about inequalities within the academy.

\section{DISCUSSION AND CONCLUSIONS}


The starting point for this chapter was the underrepresentation of women in higher education leadership, stemming from discrimination towards women working in the academy and the challenges this poses for women's identity work. The research informing this chapter suggests that in response to important identity questions: 'who am I?'- and- 'how should I act?' (Cerulo 1997), the crafting of leadership identities is a complex, contradictory and ambiguous process (Ford 2006). Added to this, competing Discourses impose demands on self-identity and the regulation of identities. Individuals may consent to such demands or resist the efforts Discourses impose by identifying with and enacting alternative Discourses such as \#feminism, but there are limits to individual agency (Alvesson and Willmott 2002).

The contribution of the chapter is both theoretical and empirical. First, theoretically, it identifies links between dominant Discourses of gender, leadership, post-feminism, neoliberalism and \#feminism, showing how these have taken root in the academy and become part of women's identities. By focusing on Discourses and related discourse, it is possible to elicit the means through which identities are crafted (Ford 2006). From a feminist poststructuralist perspective employee identity is a product of Discourses, 'some of which are enacted within the workplace, while others are broader-social in nature' (Jaros 2012: 49). This has implications for the study of identities, which this chapter sought to bring to light. There has been a tendency to neglect the role of Discourses in research into 
identities in higher education. Thus, the second contribution of the chapter has been to illustrate, through a meta-analysis of prior empirical work, how big D Discourses and little d discourses interact to reveal, for example, the 'different kinds of people' who fit in the academy, how alignments and allegiances form particular Discourses (Gee 1990).

The analysis has shown how Discourses that are taken on board contribute to the maintenance of traditional gender power relations. It illuminated individual, organisational, and historical cultural influences, showing how they reflexively interrelate to bring about identity work and identity regulation (Jaros 2012). For instance, Discourses of gender were seen to influence how women leaders in China construct identities that reflect ideal femininities in Chinese culture, but simultaneously downplay leadership as an identity.

Discourses of gender and leadership had an enduring impact the identities of women leaders in the UK and US. They were acutely aware that the leader role is incongruent with the female gender (Eagly and Karau 2002), and their gender marked them out as different. In the US study the enduring image of women as relational leaders emerged, with undertones that this might also be viewed as a weaker form of leadership. The women experienced inner angst about how they should portray themselves to fit-in and get along with colleagues. As interlopers in a male environment they endured identity anxiety. As part of negotiating legitimacy they engaged in considerable identity work. It follows that they faced a 
dilemma of giving a performance of leadership that conveyed their legitimacy in the role and enabled them to fit-in or they could exercise agency and speak out against masculine norms, but that could result in backlash and end their careers. In common with senior women leaders in the UK, many of the women in the US study resorted to projecting masculine behaviours to gain acceptance.

Faced with a constellation of competing Discourses, of gender and leadership and feminist sensibilities in their various guises, this meta-analysis has demonstrated some ways women are responding to Discourses in the identity work they do. It located post-feminism and neoliberalism as mobilising Discourses of choice and agency, where choosing to fit-in is an act of agency and choice, not discrimination. Postfeminist and neoliberal Discourse of natural sex differences, prominent in account of women's so-called natural leadership abilities or selfless leadership, also play a part inadvertently reproducing the social structure of gender inequality in the workplace by compelling women to enact identities that require considerable identity regulation. Subscribing to a postfeminist Discourse of female liberation, inadvertently limits opportunities to challenge and bring about social change. In this way complicity contributes to the continued subordination of women and gender inequalities become the norm (Gill et al. 2016).

Still, juxtaposed with this, Discourses that arise from the new feminist renaissance appeared to be taking primacy among a younger generation of women in the 
leadership pipeline. In reality is \#feminism might best be described as embryonic, but seeds of discontent have been sown from which greater equity for women may grow and bear fruit. Future research is needed to explore how this evolves over time, as well as the role the feminist renaissance plays shaping identities in the contemporary workplace. This could prove fruitful for future researchers studying women leaders in particular cultural contexts.

\section{REFERENCES}

Alvesson, M. and Due Billing, Y (2009) Understanding Gender and Organizations, Thousand Oaks: Sage.

Alvesson, M. and Willmott, H. (2002) 'Identity regulation as organisational control: Producing the appropriate individual', Journal of Management Studies, 39, 5: 619-644.

Berglund, K. Lindgren, M. and Packendorff, J. (2017) 'Responsibilising the next generation: Fostering the enterprising self through de-mobilising gender', Organization, 24, 6: 892-915.

Brink, M.C.L.v.d., Benschop, Y.W.M. and Jansen. W. (2010) 'Transparency in Academic Recruitment: a problematic tool for gender equality?' Organization Studies, 31, 12: 1-25.

Brink, M.C.L.v.d. and Benschop, Y.W.M. (2012) 'Slaying the seven-headed dragon: The quest for gender change in academia', Gender, Work \& Organization 19, 1: 71-92. 
Brooks, A. (1997) Postfeminisms: Feminism, Cultural Theory and Cultural Forms, Abingdon: Taylor \& Francis.

Burkinshaw, P. and White, K. (2017) 'Fixing the women or fixing universities: Women in HE leadership', Administrative Sciences, 7, 30: 83-96.

Convertino, C. (2019) 'Nuancing the discourse of underrepresentation: a feminist post-structural analysis of gender inequality in computer science education in the US', Gender and Education, Prepublished June 26: 1-14.

Cerulo, K. (1997) 'Identity construction: New issues, new directions', Annual Review of Sociology 23: 385-409.

Cunningham, M.E. (2016), Goods Girls Revolt: The Future of Feminism in China', World Policy Journal 33, 4: 18-22.David, M. (2015) 'Women and Gender Equality in Higher Education?', Education Sciences, 5, 1: 10-25.

Dunn, D., Gerlach, J. M., and Hyle, A. E. (2014) 'Gender and Leadership: Reflections of Women in Higher Education Administration', International Journal of Leadership and Change, 2, 1, Article 2. Online. Available HTTP: <http://digitalcommons.wku.edu/ijlc/vol2/iss1/2> (accessed 5 August 2019).

Eagly, A. H. and Karau, S. J. (2002) 'Role congruity theory of prejudice toward female leaders', Psychological Review, 109:573-598.

Ford, J. (2006) 'Discourses of leadership: Gender, identity and contradiction in a UK public sector organization', Leadership, 2, 1: 77-99.

Genz, S. and Brabon, B.A. (2009) Postfeminism, Edinburgh: Edinburgh University Press. 
Gee, J. P. (1990) Social Linguistics and Literacies: Ideology in Discourses,

Critical Perspectives on Literacy and Education, Abingdon, Oxen: Routledge.

Gill, R. (2007) 'Postfeminist media culture: elements of a sensibility', European journal of cultural studies, 10, 2: 147-166.

--- (2014) 'Unspeakable Inequalities: Post Feminism, Entrepreneurial

Subjectivity, and the Repudiation of Sexism among Cultural Workers', Social

Politics: International Studies in Gender, State and Society, 21, 4: 509-528.

--- (2016) 'Postfeminism and the new cultural life of feminism', Diffractions, 6 :

1-8. Online. Available HTPP:

<https://lisbonconsortium.files.wordpress.com/2012/12/rosalind-

gill_postfeminism-and-the-new-cultural-life-of-feminism.pdf $>$ (accessed 4

March 2019).

Gill, R. and Scharff C. (2013) 'Introduction', in R. Gill and C. Scharff (eds) New femininities, Postfeminism, Neoliberalism and Subjectivity (1-21), Houndmills, Basingstoke: Palgrave Mcmillan.

Gill, R., Kelan, E. K. and Scharff, C. M. (2017) 'A Postfeminist Sensibility at Work.' Gender, Work \& Organization, 24, 3: 226-244.

Goffman, E. (1959) The Presentation of Self in Everyday Life, Garden City: Doubleday and Company Inc.

Harding, N., Ford, J. and Gough, B. (2010) 'Accounting for ourselves: Are academics exploited workers?' Critical Perspectives on Accounting, 21, 2: 159-68. 
Harley, S. (2003) 'Research selectivity and female academics in UK Universities: From gentleman's club and barrack yard to smart macho?' Gender and Education, 15, 4: 377-92.

Ibarra, H., Carter, N. M. and Silva, C. (2010) 'Why Men Still Get More Promotions than Women', Harvard Business Review, September: 80-85. Jarboe, N. (2018) Women Count - women leaders in higher education 2018. Online. Available HTTP: <www.women-count.org> (accessed 5 August 2019). Jaros, S. (2012) 'Identity and the workplace: An assessment of contextualist and discursive approaches', Tamara Journal of Critical Organisation Inquiry, 10, 4: 45-59.

Jones, K. and Clifton, J. (2018) 'Rendering sexism invisible in workplace narratives. A narrative analysis of female entrepreneurs' stories of not being talked to by men', Gender, Work \& Organization, 25,5: 557-574.

Jones, K., Arta, A., Longman, K. L. and Remke, R. (eds) (2018) Perspectives on Women's Higher Education Leadership from around the World, Basel, Switzerland: MPDI.

Kelan, E. (2009) Performing Gender at Work, London: Sage.

Keller, J. (2011) 'Feminist editors and the new girl glossies: Fashionable feminism or just another sexist rag?', Women's Studies International Forum, 34, 1: 1-12.

Lämsä, A. M., Sintonen. T. (2001) 'A Discursive Approach to Understanding Women Leaders in Working Life', Journal of Business Ethics, 34, 3-4: 255267. 
Lewis, P. (2014) 'Postfeminism, femininities and organization studies: exploring a new agenda', Organization Studies, 35, 12: 1845-1866.

Lewis, P., Benschop, Y. and Simpson, R. (2017) 'Postfeminism, Gender and Organization. Gender', Work and Organization, 24, 3: 213-225.

Manfredi, S., Grisoni, L. and Handley, K. (2014) Researching the Careers of Top Management Programme Alumni, London: Report for Leadership Foundation for Higher Education.

McRobbie, A. (2009) The Aftermath of Feminism: Gender, Culture and Social Change, London: Sage Publications.

Morley, L. (2010) 'Hyper modernization and Archaism: Women in Higher Education Internationally', in B Riegraf, B. Aulenbacher, E. Kirsch-Auwärter, U Müller. Gender Change in Academia: Re-Mapping the Fields of Work, Knowledge, and Politics from a Gender Perspective (27-42), Wiesbaden: Springer.

--- (2013) Women and Higher Education Leadership: Aspirations and Absences, London: Leadership Foundation for Higher Education.

Morley, L. and Crossouard, B. (2016) 'Gender in the neoliberalised global academy: the affective economy of women and leadership in south asia,' British Journal of Sociology of Education, 37: 149-68.

O'Doherty, D. and Willmott, H. (2001) 'The question of subjectivity and the labour process', International Studies of Management and Organization, 30:112-131. 
O'Connor, P. (2014) Management and Gender in Higher Education, Manchester: Manchester University Press.

Rottenberg, C. (2013) 'The Rise of Neoliberal Feminism', Cultural Studies, 28, 3): $418-437$.

--- (2018) 'How Neoliberalism was Colonised by Feminism - and what you can do about it', The Conversation. Online. Available HTTP:

<http://www.theconversation.com> (accessed 10 October 2018).

Savigny, H. (2014) 'Women, know your limits: cultural sexism in academia', Gender and Education, 26, 7: 794-809.

Shepherd, S. (2017) 'Why are there so few female leaders in higher education? A case of structure or agency?' Managament in Education, 31: 82-87.

Singh, J.K.S. (2008) Whispers of Change Female Staff Numbers in Commonwealth Universities, Report for Association of Commonwealth Universities (London).

Thornham, S. and Pengpeng, F. (2010) '"Just a Slogan": Individualism, postfeminism, and female subjectivity in consumerist China', Feminist Media Studies 10, 2: 195-211.

Times Higher Education (2019) International Women's Day: top 10 universities led by women. Online. Available HTTP: <https://www.timeshighereducation.com/student/best-universities/top-10universities-led-women> (accessed 25 March 2019). 
Vicary, A. and Jones, K. (2017) 'The Implications of Contractual Terms of Employment for Women and Leadership: an autoethnographic study in UK higher education', Administrative Sciences 7, 20: 55-68.

Weedon, C. (1997) Feminist Practice and Poststructuralist Theory, Oxford: Blackwell.

Wiggins, S. (2017) Discursive Psychology, London: Sage Publications Ltd. Zhao, J. and Jones. K. (2017) 'Women and Leadership in Higher Education in China: Discourse and the Discursive Construction of Identity', Administrative Sciences, 7, 21: 128-144. 